\title{
Parasites of fish Poecilia velifera and their potential as bioindicators of wetland restoration progress
}

Francisco N. Morales-Serna ${ }^{1,2^{*}}$, María A. Rodríguez-Santiago ${ }^{1,3}$, Rolando Gelabert ${ }^{3}$ and Luz M. Flores-Morales ${ }^{3}$

\begin{abstract}
Fish harbor a high diversity of parasites that play an important role for the ecosystem. Because these parasites have different life-cycle traits, changes in their populations or communities may provide useful information related to ecosystem health. Highly stressful conditions may reduce parasite communities or populations. However, it is not a rule since host-parasite interactions are hardly predictable. In this study, macroparasites of the fish sailfin molly (Poecilia velifera) from three sites (conserved, degraded and under restoration) located within a mangrove wetland area, in the Terminos Lagoon (southern Gulf of Mexico), were analyzed in order to determine their potential use as bioindicators. A total of 198 fish were examined for parasites. Six parasite species were found: two crustaceans (Argulus sp. and Ergasilus aff. cerastes), one trematode (Centrocestus formosanus), one monogenean (Gyrodactylus sp.) and two nematodes (Contracaecum sp. and Cuculanus sp.). There were no significant differences in the structure of parasite infracommunities as well as in prevalence and intensity of parasite populations between degraded and conserved sites. However, the site under restoration had poorer infracommunities and smaller populations of crustaceans and trematodes, which suggests that restoration efforts have not improved the ecological conditions. Based on these results, it is conjectured that parasites of $P$. velifera did not show useful information to provide a diagnosis related to ecosystem health. Beyond this ecological subject, the present study represents new host record for most parasite species found.
\end{abstract}

Keywords: Helminths, Crustaceans, Tropical coastal lagoon, Poeciliidae

\section{Background}

Global wetland areas are highly valuable in terms of biodiversity and ecosystem services such as regulation of water quality, protection against extreme events, carbon management, and proportion of food; however, about $50 \%$ of them has been lost because of human impact $[1,2]$. In tropical regions, coastal wetlands are important for reducing the negative effects of windstorms, so loss of vegetation can increase the vulnerability of these areas to more incidences of natural disasters [3]. Therefore, ecological restoration has been developed in order to recover the health, integrity, and sustainability of wetlands worldwide.

\footnotetext{
*Correspondence: francisco.morales@ciad.mx

${ }^{1}$ Consejo Nacional de Ciencia y Tecnología (CONACYT), Ciudad de México, Mexico

Full list of author information is available at the end of the article
}

Evaluating wetland restoration often requires detailed long-term observations of ecological variables related to soil (e.g. organic content) and water quality (e.g. dissolved oxygen), as well as abundance and diversity of plants and free-living animals [4-6]. The use of aquatic parasites as indicators has been very limited despite the fact that they may provide useful information about the ecosystem health.

At community level it has been proposed that the higher the richness in parasites, the healthier the ecosystem $[7,8]$. The underlying principle of parasites as ecosystem health indicators lies in their life-cycle $[7,9]$. Endoparasites generally have an indirect life-cycle involving two or more host species; therefore, the absence of a single endoparasite species would be indicating the absence of at least one host in the ecosystem, which could be attributable to an environmental disturbance. Ectoparasites which typically have a direct life-cycle are 
also useful bioindicators as they may directly respond to changes in their environment. For instance, at low to moderate stress host defense may result compromised leading to high infection levels of ectoparasites, but at higher stress levels the number of ectoparasites may be reduced due to the direct negative effect of the stressor $[10,11]$. However, although parasite community parameters (e.g. richness) may be informative, it has been suggested that parasite population parameters are slightly more responsive to stress [12].

We contend that parasitological data should be integrated into coastal wetland restoration projects. A few studies have shown that prevalence and diversity of trematodes in snails reflect degradation and recovery of coastal wetlands $[13,14]$. However, it is necessary to investigate whether other host-parasite systems may provide useful information for this task.

In the southern Gulf of Mexico, the Terminos Lagoon is one of the most important coastal wetlands in the Yucatan Peninsula region of Mexico. It has historically been impacted by anthropogenic and natural phenomena, generating some destruction of the mangrove forest [15-17]. In 2010, the Research Center of Environmental Sciences of the Universidad Autónoma del Carmen (UNACAR) started a mangrove restoration project in an area named Bahamitas. Five years later, personnel from the Laboratorio de Zoología, Facultad de Ciencias Naturales, UNACAR performed monitoring to determine the abundance and distribution of the fish sailfin molly (Poecilia velifera) to evaluate the restoration progress within that area (unpublished data). This fish species is endemic to the Yucatán Peninsula, restricted to coastal habitats, particularly those with low flow regimes, such as anchialine cenotes and salt marshes, where the fish are prey of fish, birds, and crocodiles [18]. Fish were not specifically collected for parasitological analysis; however, we were allowed to examine some samples. The goal of this paper was to analyze the macroparasite communities of $P$. velifera and determine their potential utility as bioindicators of the wetland restoration progress.

\section{Materials and methods}

\section{Fish sampling and parasitological examination}

The Terminos Lagoon (Fig. 1), located in the southern Gulf of Mexico, is a complex system of $2500 \mathrm{~km}^{2}$ and mean depth of $3.5 \mathrm{~m}$, constituted by estuaries, lagoons, wetlands and associated terrestrial ecosystems [19]. Fish were captured by the Laboratorio de Zoología, Facultad de Ciencias Naturales, UNACAR, with funnel-type minnow traps and, after euthanasia, preserved in $70 \%$ alcohol. Water depth was measured with a measuring rod with $1-\mathrm{cm}$ precision, and water temperature, salinity, dissolved oxygen, and $\mathrm{pH}$ were measured with a portable multiparameter (YSI 63) at each sampling site.

For this study, we selected fish samples $(n=198)$ caught in three sites with different mangrove forest covers. The sites were termed conserved ( $\mathrm{n}=50$ fish), degraded ( $\mathrm{n}=78 \mathrm{fish}$ ) and under restoration ( $\mathrm{n}=70$ fish) (Fig. 1). The conserved site $\left(18^{\circ} 41^{\prime} 1.7^{\prime \prime} \mathrm{N}, 91^{\circ} 39^{\prime} 2.7^{\prime \prime} \mathrm{W}\right)$ is a channel permanently connected with the lagoon, with a mean depth of $1.2 \mathrm{~m}$, mean salinity of $32.1 \%$, mean temperature of $29.1{ }^{\circ} \mathrm{C}$, mean dissolved oxygen concentration of $7.3 \mathrm{mg} / \mathrm{L}$, and mean $\mathrm{pH}$ of 8 , bordered by mangroves (Rizophora mangle and Avicenia germinans). The degraded site $\left(18^{\circ} 41^{\prime} 29^{\prime \prime} \mathrm{N}, 91^{\circ} 38^{\prime} 10^{\prime \prime} \mathrm{W}\right)$ is a channel with mean depth of $0.4 \mathrm{~m}$, mean salinity of $30.5 \%$, mean temperature of $31.6{ }^{\circ} \mathrm{C}$, mean dissolved oxygen concentration of $5 \mathrm{mg} / \mathrm{L}$, and mean $\mathrm{pH}$ of 7.9, bordered by short mangrove and a few tall, mostly dead trees. Degradation was most likely due to the isolation of the channel from the lagoon propitiated by the sand accumulation as consequence of both anthropogenic activities and hurricanes that have pounded the Yucatán Peninsula. At the site under restoration $\left(18^{\circ} 40^{\prime} 17.1^{\prime \prime} \mathrm{N}, 91^{\circ} 40^{\prime} 26.7^{\prime \prime} \mathrm{W}\right)$ the main conservation strategy was the creation of an artificial channel in 2010. Before the restoration efforts, this site was characterized by the accumulation of sand and predominantly dead vegetation; however, during the present study 5 years later the channel was characterized by a mean depth of $0.5 \mathrm{~m}$, mean salinity of $31.5 \%$, mean temperature of $30.7^{\circ} \mathrm{C}$, mean dissolved oxygen concentration of $8.1 \mathrm{mg} / \mathrm{L}$, and mean $\mathrm{pH}$ of 8 , bordered by new mangrove plants and pioneer vegetation.

Total body length $(\mathrm{mm})$ was measured for each fish prior to necropsy. Fish fins, body, and gills were examined for macro-ectoparasites, whereas liver, gastrointestinal tract, heart, kidney, and gonads compressed between two glass plates were examined for macro-endoparasites under a dissection microscope. Helminth parasites were carefully removed and counted, fixed and stained or cleared pending on the taxonomic group [20]. Crustacean parasites were fixed in $70 \%$ alcohol and cleared in glycerine alcohol. Parasites were observed under a Stemi DV4-Zeiss microscope to perform identification to the lowest practicable taxonomic level.

\section{Data analyses}

Possible differences in total length of fish among sampling sites were determined with an ANOVA test in SigmaStat 3.0 software. All parasite ecology terminology follows definitions of Bush et al. [21]. Parasite communities were analyzed at infracommunity (all parasites in an individual host) level through the mean species richness per host, mean number of parasite individuals per host, mean Brillouin diversity index per host, and mean 


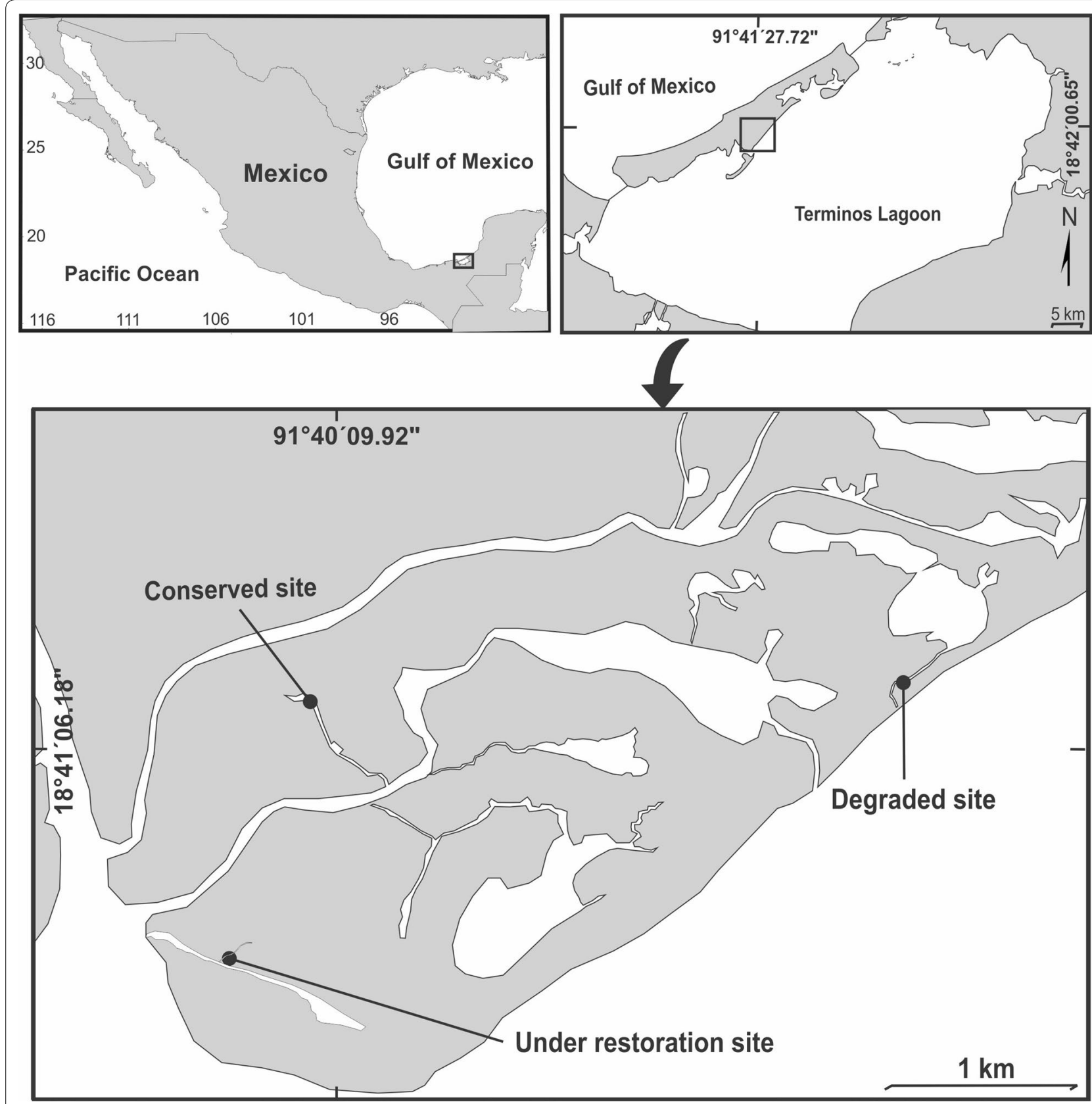

Fig. 1 Map of the Terminos Lagoon in the southern Gulf of Mexico, showing the three sampling sites during the present study

Berger-Parker dominance index per host. These indices were compared among sampling sites with Kruskal-Wallis tests and Dunn's method as a posteriori test in SigmaStat 3.0 software. In addition, to detect any possible difference between communities, a non-metric multidimensional scaling (MDS) plot and a one-way analysis of similarity (ANOSIM) on ranked square root-transformed Bray-Curtis dissimilarities were performed with
PRIMER 6.0 software. Uninfected fish were excluded from infracommunity analyses.

Prevalence (percentage of hosts from a sample infected with a particular parasite) and mean intensity (average number of a particular parasites in infected host individuals in a sample), with their respective $95 \%$ confidence intervals, were determined for each parasite taxa using Quantitative Parasitology on the Web (QPweb) software $[22,23]$. Differences in prevalence and mean intensity of 
the commonest species (prevalence $>10 \%$ ) between sites were detected with Fisher's exact test and bootstrap $t$ test (2000 replications) in QPweb. Significant differences were established when $P<0.05$.

\section{Results}

Median values of fish total length were ca. $40 \mathrm{~mm}$ and did not vary significantly $(P>0.05)$ among sampling sites. A total of six macroparasite species were found: two crustaceans (Argulus sp. and Ergasilus aff. cerastes), one trematode (Centrocestus formosanus), one monogenean (Gyrodactylus sp.) and two nematodes (Contracaecum sp. and Cuculanus sp.). The proportions of fish harboring at least one parasite species were $96 \%, 78 \%$ and $80 \%$ in the conserved, degraded and under restoration sites, respectively. No fish was parasitized by all six parasite species simultaneously. The maximum infracommunity species richness (4 species) was found in only three hosts from the conserved site. Species richness, Brillouin diversity index, and Berger-Parker dominance index were similar between conserved and degraded sites, and significantly higher $(P<0.05)$ than in the site under restoration, whereas the number of parasite individuals was higher $(P<0.05)$ in the conserved than in the other sites (Fig. 2). However, MDS shows similar structure of infracommunities between sites (Fig. 3), which was confirmed by the ANOSIM (Global R=0.033, $P<0.05$ ).

Prevalences and mean intensities of infection are given in Tables 1 and 2, respectively. Centrocestus formosanus showed the highest infection level. Also Argulus sp., E. aff. cerastes, and Cuculanus sp. were common species. All except Argulus sp. showed significant differences $(P<0.05)$ in prevalence among sampling sites. Prevalences of $E$. aff. cerastes and Cuculanus sp. were significantly lower in the site under restoration than in conserved and degraded sites, but their mean intensities did not change. Prevalence and mean intensity of $C$. formosanus were lower in both degraded and under restoration sites than in the conserved site.

\section{Discussion}

\section{Parasites as bioindicators}

The very low dissimilarity of infracommunities between sites, as indicated by the global R from ANOSIM, and by the lack of significant differences in species richness, diversity index, and dominance index between conserved and degraded sites, suggest that the ecological conditions (e.g. mangrove coverage) at those sampling sites were not reflected in the structure of the parasite infracomunities of $P$. velifera. It was probably due to the fact that stressinduced decreases in one species can be countered by increases in another [12]. Even so, the site under restoration showed a significantly lower diversity of parasites,
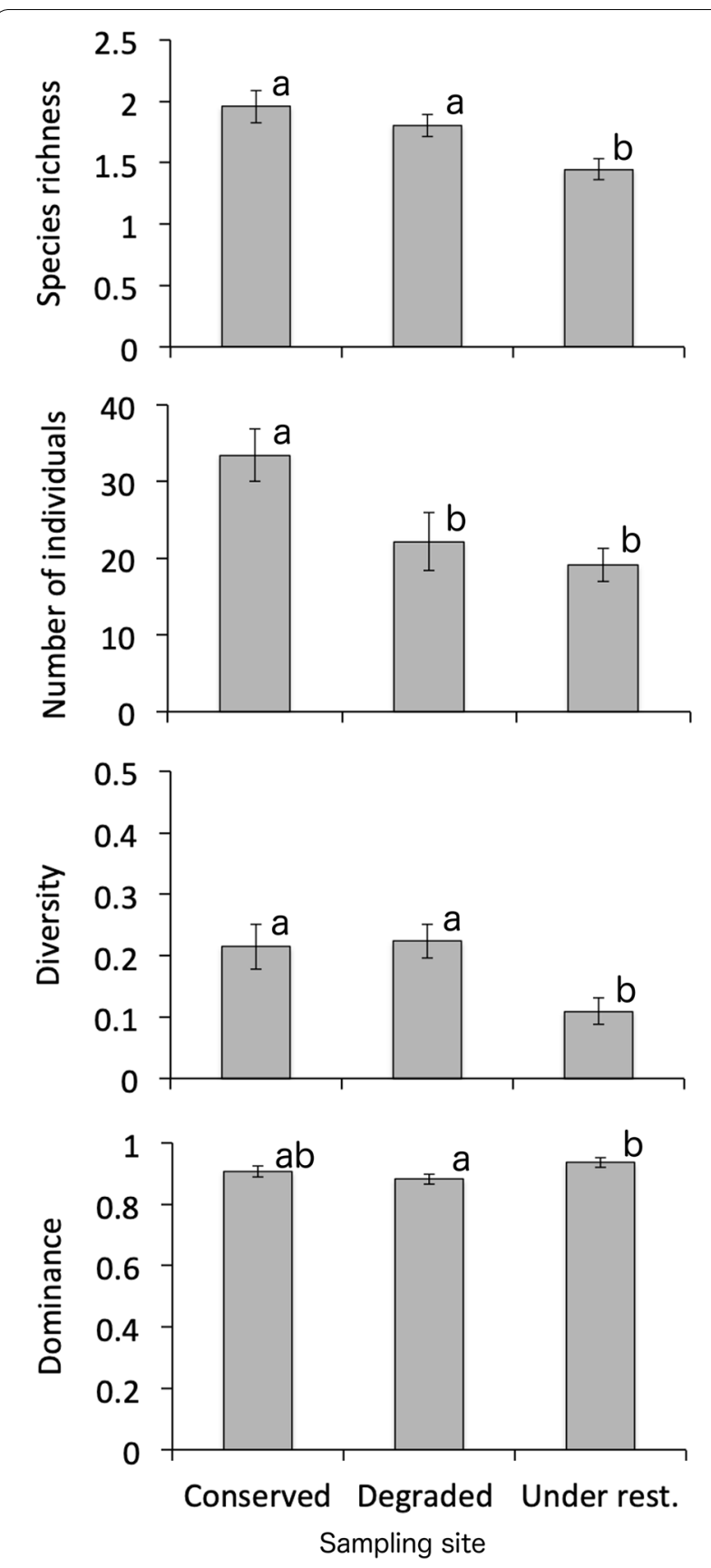

Fig. 2 Mean \pm standard error of parasite species richness, number of parasite individuals, Brillouin diversity index, and Berger-Parker dominance index in sailfin molly (Poecilia velifera) from three sites in Bahamitas, Terminos Lagoon. Different letters indicate significant differences between sites

which suggests that restoration efforts have not improved the ecological conditions, at least not to be comparable with the conserved site. According to Marcogliese [7], perturbations in ecosystem structure and function that affect food web topology may also affect parasite transmission, which impacts upon parasite species abundance 


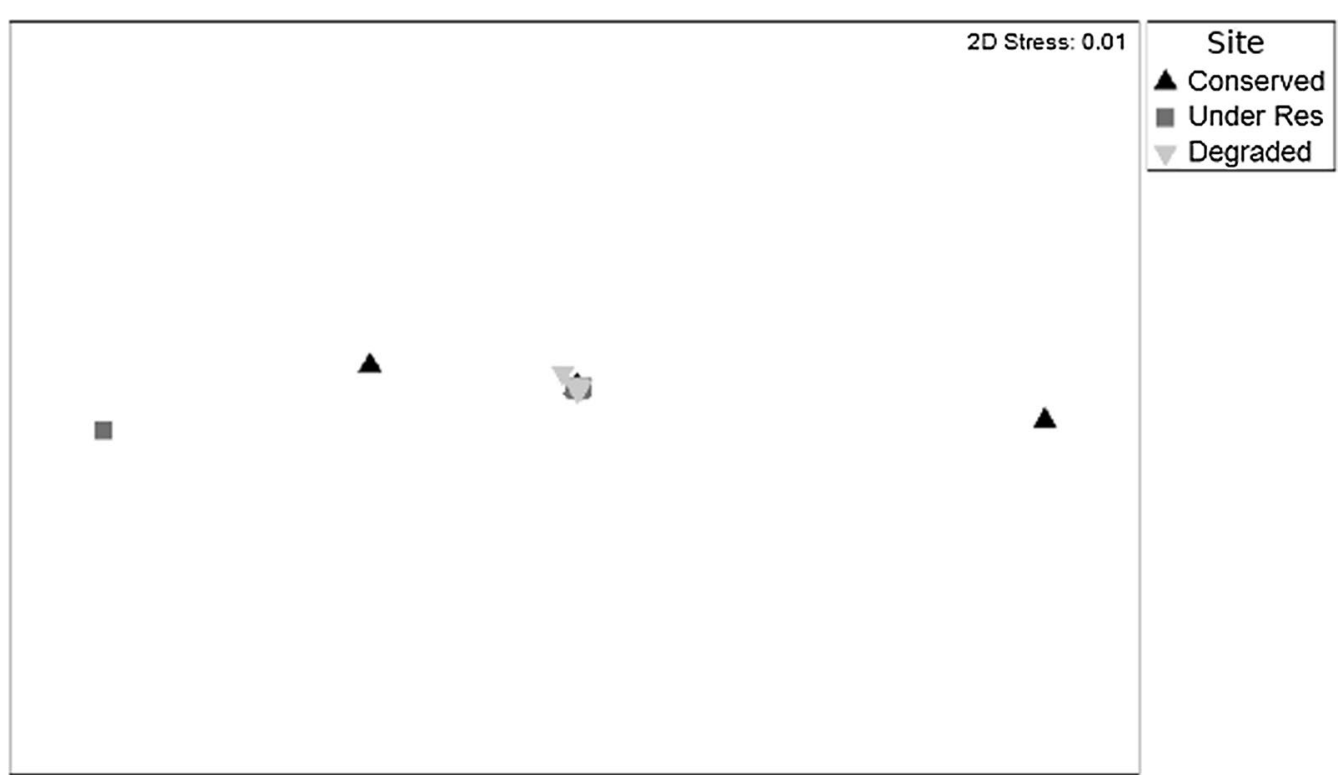

Fig. 3 Two-dimensional nonmetric MDS plot of Bray-Curtis similarity based on data of macroparasite infracommunities of Poecilia velifera from three sites in Bahamitas, Terminos Lagoon

Table 1 Prevalence (95\% confidence interval) of macroparasite species found in Poecilia velifera from three sampling sites in Bahamitas, Terminos Lagoon

\begin{tabular}{lccc}
\hline Parasites & Conserved & Degraded & Under restoration \\
\hline Crustacea & & & $11.5(5.4-20.8)^{\mathrm{a}}$ \\
$\quad$ Argulus sp. (A) & $28(16.2-42.5)^{\mathrm{a}}$ & $46.2(34.8-57.8)^{\mathrm{a}}$ & $17.1(9.2-28)^{\mathrm{a}}$ \\
$\quad$ Ergasilus aff. cerastes (A) & $42(28.2-56.8)^{\mathrm{a}}$ & & $22.9(13.7-34.4)^{\mathrm{b}}$ \\
$\begin{array}{l}\text { Trematoda } \\
\text { Centrocestus formosanus (L) }\end{array}$ & $92(80.8-97.8)^{\mathrm{a}}$ & $74.4(63.2-83.6)^{\mathrm{b}}$ & $74.3(62.4-84)^{\mathrm{b}}$ \\
Monogenea & $2(0.1-10.6)$ & $5.1(1.4-12.6)$ & $8.6(3.2-17.7)$ \\
$\quad$ Gyrodactylus sp. (A) & & & 0 \\
Nematoda & $2(0.1-10.6)$ & $1.3(0-6.9)$ & 0 \\
$\quad$ Contracaecum sp. (L) & $14(5.8-26.7)^{\mathrm{a}}$ & $9(3.7-17.6)^{\mathrm{a}}$ & $0^{\mathrm{b}}$ \\
Cuculanus sp. (L) & & \\
\hline
\end{tabular}

Values marked with superscript letters in common or no letters indicate no significant difference between sampling sites (Fisher's exact test, $P>0.05$ )

$A$ adult stage, $L$ larva stage

and composition. It is a very complex issue given the difficulty of determining the particular mechanisms driving differences in parasite community dynamics (e.g. [24]). Nonetheless, it has been observed that ecological disturbance has a negative impact on parasite diversity. For instance, Krause et al. [8] observed that fish Etheostoma nigrum from polluted sites had significantly lower numbers of parasite individuals and species richness than fish from reference sites.

At population level, given that prevalence and intensity of ectoparasite species E. aff. cerastes and Argulus sp. were practically similar between sites, it could be assumed that water quality did no changed through the study area. The exception was the significantly lower prevalence of Ergasilus aff. ceraste in the site under restoration, which could be indicating (to some extent) poorer water quality than in the other sampling sites and, therefore, poor progress in the successful restoration of Bahamitas after 5 years. We got this conjecture considering the fact that ectoparasites are in direct contact with their environment and poor water quality may reduce their vitality or increase their mortality $[9,12]$. The prevalence of Argulus sp. was also lower in the site under restoration than in the conserved, but the difference was not significant. 
Table 2 Mean intensity (95\% confidence interval) of macroparasite species found in Poecilia velifera from three sampling sites in Bahamitas, Terminos Lagoon

\begin{tabular}{|c|c|c|c|}
\hline Parasites & Conserved & Degraded & Under restoration \\
\hline \multicolumn{4}{|l|}{ Crustacea } \\
\hline Argulus sp. & $1.9(1.4-2.4)^{\mathrm{a}}$ & $1.7(1.2-2)^{\mathrm{a}}$ & $1.25(1-1.4)^{\mathrm{a}}$ \\
\hline Ergasilus aff. cerastes & $2.9(2.0-4.5)^{\mathrm{a}}$ & $3.19(2.3-4.6)^{\mathrm{a}}$ & $1.9(1.4-2.6)^{\mathrm{a}}$ \\
\hline \multicolumn{4}{|l|}{ Trematoda } \\
\hline Centrocestus formosanus & $31.2(25.2-39.1)^{\mathrm{a}}$ & $21(15.3-32.2)^{\mathrm{b}}$ & $19.6(16-25.2)^{b}$ \\
\hline \multicolumn{4}{|l|}{ Monogenea } \\
\hline Gyrodactylus sp. & 1 & 1 & $1.2(1-1.5)$ \\
\hline \multicolumn{4}{|l|}{ Nematoda } \\
\hline Contracaecum sp. & 1 & 1 & 0 \\
\hline Cuculanus sp. & $1.9(1-2.7)^{\mathrm{a}}$ & $1^{\mathrm{a}}$ & $0^{\mathrm{a}}$ \\
\hline
\end{tabular}

Values marked with superscript letters in common or no letters indicate no significant difference between sampling sites ( $t$-bootstrap test, $P>0.05$ )

Likewise, the significantly lower prevalence and intensity of $C$. formosanus in the under restoration and degraded sites may indicate more unfavorable ecological conditions than in the conserved site, where the infection levels of C. formosanus were significantly higher. This parasite requires three host species (snail, fish, and fisheating birds) to complete their life cycle. We conjecture that the scarce vegetation bordering the under restoration and degraded sites provoked a decrease in abundance of the final bird host which resulted in a decrease of $C$. formosanus population. When Huspeni and Lafferty [13] evaluated a saltmarsh restoration project, they observed that the prevalence of trematodes of snails (Cerithidea californica) increased in restored sites, which was attributed to an increased bird presence. Aguirre-Macedo et al. [14] observed that the populations of trematodes of snails (Cerithidea pliculosa) decreased after a hurricane, but then started to increase and in 6 years reached parameters similar to those before the hurricane, indicating the ecosystem recovery. Taglioretti et al. [24] showed that the susceptibility of fish-trematode systems to variations in both biotic and abiotic stressors makes them a promising tool for detecting disturbances in aquatic ecosystems. Therefore, trematodes are seen as promising effect indicators so that prevalence is inversely related to the degree of disturbance of aquatic ecosystems [9, 24].

Nonetheless, the use of C. formosanus as bioindicator has to be taken with caution since it is an invasive trematode, which was introduced to Mexico in 1979 with its intermediate snail host (Melanoides tuberculata) and was able to disperse through a variety of fresh- or brackish-water fish in different regions of the country, reaching extraordinarily high infection levels [25]. The snail M. tuberculata has already been reported from the Terminos Lagoon [26], possibly at high abundance since this successful invasive species may be more tolerant to abiotic stressors than native species [27]. This possible high abundance of the first intermediate host plus its low preference for a particular fish host species could account for the high proliferation of $C$. formosanus.

As mentioned initially, our fish samples were not originally collected for parasitological analysis. Therefore, one shortcoming of this study is the lack of a proper study design, including perhaps more contrasting or distant sampling sites, replication of sites, and examination of freshly sacrificed fish, since preservation prior to dissection results in incomplete quantitative and qualitative data [28]. This situation could have influenced that our parasitological data did not show useful information to provide a confident diagnosis related to ecosystem health. However, in the particular case of the restoration project, the low abundance of trematodes and crustaceans may suggest that strategies of restoration should be improved to achieve better results.

\section{New host-parasite records}

Four out of six parasite species herein reported are helminths. According to previous studies, $P$. velifera is the potential host of at least 11 helminth species: Contracaecum sp., Atrophecaecum astorquii, Stunkardiella minima, Clinostomum complanatum, Saccocoelioides sogandaresi, Ascocotyle tenuicollis, A. megalocephala, A. diminuta, A. macrostoma, A. nana, and Proterodiplostomidae gen. sp. [29-32]. These records are from freshwater habitats so that their absence in brackish water of the Terminos Lagoon is not surprising. However, except for Contracaecum sp., the parasites we found in P. velifera have not been previously recorded in this fish. The presence of these parasites may be explained by the ecological characteristics of the Terminos Lagoon, which is influenced by both marine and freshwater ecosystems that favor biodiversity, particularly in the interlinked 
mangrove-seagrass habitat where the highest number of trophic levels may be observed [33].

To the best of our knowledge, the present study represents the first record of a species of Gyrodactylus on P. velifera. According to García-Vásquez et al. [34], 19 species of Gyrodactylus are known to infect poeciliid fishes but $P$. velifera does not appear in the list. There are approximately 450 species of Gyrodactylus for which delimitation currently requires not only morphometrics but also molecular analyses, a task beyond the scope of the present research. Recently, García-Vásquez et al. [35] pointed out that poeciliids could contribute to the spread of Gyrodactylus cichlidarum, which is a serious pathogen for tilapia. Thus, a more precise identification of the species found in P. velifera is necessary.

Other interesting findings in this study were the parasitic crustaceans; however, a detailed taxonomic study for the correct species designation is needed. Species of Argulus and Ergasilus are typically found on brackishwater fish; however, they have not previously been reported from $P$. velifera. Ergasilus is a polyphyletic genus that includes approximately 180 nominal species whose delimitation may be confused because of insufficient detail in some older published descriptions [36, 37]. The species of Argulus found in the present study morphologically resembles $A$. elongatus and $A$. izintwala, which are distinguished from congeners by their elongated body and a carapace covering only the base of the first pair of legs [38]. We suspect that our specimens represent a new species but a deeper taxonomic study is required.

\section{Authors' contributions}

FNMS participated in the study design, supervised the data analyses, interpreted data, and wrote the manuscript. MARS conceived the study, secured funding and supervised fish examination and parasite identification. RG provided resources and helped with the interpretation of the results. This study is part of the M.Sc. thesis of LMFM, who collected and identified parasite species, performed data analyses and interpreted the results. All authors read and approved the final manuscript.

\section{Author details}

${ }^{1}$ Consejo Nacional de Ciencia y Tecnología (CONACYT), Ciudad de México, Mexico. ${ }^{2}$ Centro de Investigación en Alimentación y Desarrollo, A.C. Unidad Mazatlán en Acuicultura y Manejo Ambiental, 82112 Mazatlán, Sinaloa, Mexico. ${ }^{3}$ Centro de Investigación de Ciencias Ambientales, Facultad de Ciencias Naturales, Universidad Autónoma del Carmen, 24155, Ciudad del Carmen, Campeche, Mexico.

\section{Acknowledgements}

This study was supported by the Laboratorio de Parasitologia Ambiental from the Research Center of Enviromental Science (CICA), UNACAR. We would like to thank Roberto Brito Pérez, Enrique Amador-del Ángel and Hiram Reyna-Ramos for providing us the fish samples obtained through the DACNAT/2014/06 project. We thank Julio César Canales-Delgadillo for his help in carrying out some statistical analyses. We are grateful to Karen Englander (Faculty of Languages, University of Baja California) for her English review and editing of the manuscript. LMFM thanks the National Council of Science and Technology of Mexico (CONACYT) for her graduate scholarship.

\section{Competing interests}

The authors declare that they have no competing interests.

\section{Availability of data and materials}

All data generated or analyzed during this study are included in this published article. Datasets are available from the corresponding author on request.

\section{Consent for publication}

Not applicable.

\section{Ethics approval}

The authors followed the Ethical Responsibilities according to the Committee on Publication Ethics (COPE).

\section{Publisher's Note}

Springer Nature remains neutral with regard to jurisdictional claims in published maps and institutional affiliations.

Received: 24 October 2018 Accepted: 10 January 2019

Published online: 17 January 2019

\section{References}

1. Zedler JB, Kercher S. Wetland resources: status, trends, ecosystem services, and restorability. Ann Rev Environ Res. 2005;30:39-74.

2. Meli P, Rey Benayas JM, Balvanera P, Martínez Ramos M. Restoration enhances wetland biodiversity and ecosystem service supply, but results are context-dependent: a meta-analysis. PLoS ONE. 2014;9(4):e93507.

3. Barbier EB. Valuing ecosystems services as productive inputs. Econom Policy. 2007;22:178-229.

4. Neckles HA, Dionne M, Burdick DM, Roman CT, Buchsbaum R, Hutchins E. A monitoring protocol to assess tidal restoration of salt marshes on local and regional scales. Restor Ecol. 2002;10:556-63.

5. Liu G, Tian K, Sun J, Xiao D, Yuan X. Evaluating the effects of wetland restoration at the watershed scale in northwest Yunnan Plateau, China. Wetlands. 2016;36:169-83.

6. Zhao Q, Bai J, Huang L, Gu B, Lu Q, Gao Z. A review of methodologies and success indicators for coastal wetland restoration. Ecol Indic. 2016;60:442-52.

7. Marcogliese DJ. Parasites of the superorganism: are they indicators of ecosystem health? Int J Parasitol. 2005;35:705-16.

8. Krause RJ, McLaughlin D, Marcogliese DJ. Parasite fauna of Etheostoma nigrum (Percidae: Etheostomatinae) in localities of varying pollution stress in the St. Lawrence River, Quebec, Canada. Parasitol Res. 2010;107:285-94.

9. Sures B, Nachev M, Selbach C, Marcogliese DJ. Parasite responses to pollution: what we know and where we go in "Environmental Parasitology". Parasit Vec. 2017;10:65.

10. Gheorghiu C, Cable J, Marcogliese DJ, Scott M. Effects of waterborne zinc on reproduction, survival and morphometrics of Gyrodactylus turnbulli (Monogenea) on guppies (Poecilia reticulata). Int J Parasitol. 2007;37:375-81.

11. Gheorghiu C, Marcogliese DJ, Scott M. Concentration-dependent effects of waterborne zinc on population dynamics of Gyrodactylus turnbulli (Monogenea) on isolated guppies (Poecilia reticulata). Parasitology. 2006;132:225-32.

12. Blanar CA, Munkittrick KR, Houlahan J, MacLatchy DL, Marcogliese DJ. Pollution and parasitism in aquatic animals: a meta-analysis of effect size. Aquat Toxicol. 2009;93:18-28.

13. Huspeni TC, Lafferty KD. Using larval trematodes that parasitize snails to evaluate a saltmarsh restoration project. Ecol Appl. 2004;14:795-804.

14. Aguirre-Macedo ML, Vidal-Martínez VM, Lafferty KD. Trematode communities in snails can indicate impact and recovery from hurricanes in a tropical coastal lagoon. Int J Parasitol. 2011;41:1403-8.

15. Soto-Galera E, Piera J, López P. Spatial and temporal land cover changes in Terminos Lagoon Reserve, Mexico. Rev Biol Trop. 2010;58:565-75.

16. Villéger S, Ramos Miranda J, Flores Hernández D, Mouillot D. Contrasting changes in taxonomic vs. functional diversity of tropical fish communities after habitat degradation. Ecol Appl. 2010;20:1512-22. 
17. Magallanes-Ordóñez VR, Marmolejo-Rodríguez AJ, Rodríguez-Figueroa GM, Sánchez-González A, Aguiñiga-García S, Arreguín-Sánchez F, et al. Characterization of lithogenic and biogenic zones and natural enrichment of nickel in sediments of the Terminos Lagoon, Campeche, Mexico. Est Coast Shelf Sci. 2015;156:116-23.

18. Hankison SJ, Childress MJ, Schmitter-Soto JJ, Ptacek MB. Morphological divergence within and between the Mexican sailfin mollies, Poecilia velifera and Poecilia petenensis. J Fish Biol. 2006;68:1610-30.

19. García-Ríos V, Alpuche-Gual L, Herrera-Silveira J, Montero-Muñoz J, Morales-Ojeda S, Pech D, et al. Towards a coastal conditions assessment and monitoring of the Gulf of Mexico Large Marine Ecosystem (GoM LME): terminos Lagoon pilot site. Environ Dev. 2013;7:72-9.

20. Vidal-Martínez V, Aguirre-Macedo L, González-Solís D, Mendoza-Franco E. Atlas of the helminth parasites of cichlid fish of Mexico. Prague: Academia; 2001.

21. Bush AO, Lafferty KD, Lotz JM, Shostak AW. Parasitology meets ecology on its own terms: Margolis et al., revisited. J Parasitol. 1997;83:575-83.

22. Rozsa L, Reiczigel J, Majoros G. Quantifying parasites in samples of hosts. J Parasitol. 2000;86:228-32.

23. Reiczigel J, Rozsa L, Reiczigel A, Fabian I. Quantitative Parasitology (QPweb). 2013. http://www2.univet.hu/qpweb.

24. Taglioretti V, Rossin MA, Timi JT. Fish-trematodes systems as indicators of anthropogenic disturbance: effects of urbanization on a small stream. Ecol Indic. 2018;93:759-70.

25. ScholzT, Salgado-Maldonado G. The introduction and dispersal of Centrocestus formosanus (Nishigori, 1924) (Digenea: Heterophyidae) in Mexico: a review. Am Midl Nat. 2000;143:185-200.

26. Amador-del Ángel LE, Endañú-Huerta E, López-Contreras JE, WakidaKusunoki AT, Guevara Carrió E, Brito Pérez R. Fauna exótica establecida e invasora en el Área de Protección de Flora y Fauna Laguna de Términos, Campeche: estado actual, impactos, necesidades y perspectivas. In: Frutos Cortés M, Amador-del Ángel LE, editors. Problemas contemporáneos regionales del sureste mexicano. El caso del estado de Campeche. Campeche: Universidad Autónoma del Carmen; 2015. p. 234-79.

27. Weir SM, Salice CJ. High tolerance to abiotic stressors and invasion success of the slow growing freshwater snail, Melanoides tuberculatus. Biol Invasions. 2012;14:385-94.

28. Kvach Y, Ondračková M, Janáč M, Jurajda P. Methodological issues affecting the study of fish parasites. III. Effect of fish preservation method. Dis Aquat Org. 2018;127:213-24.
29. Pérez-Ponce de León G, García-Prieto L, Osorio-Sarabia D, León-Regagnon V. Listado Faunístico de México. VI. Helmintos parásitos de peces de aguas continentales de México. México, D.F.: Instituto de Biología, Universidad Nacional Autónoma de México; 1996.

30. Aguirre-Macedo ML, Scholz T, González-Solís D, Vidal-Martínez VM, Posel P, Arjona-Torres $G$, et al. Larval helminths parasitizing freswater fishes from Atlantic coast of Nicaragua. Comp Parasitol. 2001;68:42-51.

31. Gibson DI, Bray RA, Harris EA (Compilers). Host-parasite database of the natural history museum, London; 2005. http://www.nhm.ac.uk/researchcuration/scientific-resources/taxonomy-systematics/host-parasites/index .html. Accessed 16 Oct 2018.

32. Pineda-López R, Salgado-Maldonado G, Soto-Galera E, HernándezCamacho N, Orozco-Zamorano A, Contreras-Robledo S, et al. Helminth parasites of viviparous fishes in Mexico. In: Grier HJ, Uribe MC, editors. Viviparous fishes. Florida: New Life Publications, Homestead; 2005. p. 437-56.

33. Sepúlveda-Lozada A, Mendoza-Carranza M, Wolff M, Saint-Paul U, Ponce-Mendoza A. Differences in food web structure of mangroves and freshwater marshes: evidence from stable isotope studies in the Southern Gulf of Mexico. Wetl Ecol Manag. 2015;23:293-314.

34. García-Vásquez A, Razo-Mendivil U, Rubio-Godoy M. Morphological and molecular description of eight new species of Gyrodactylus von Nordmann, 1832 (Platyhelminthes: Monogenea) from poeciliid fishes, collected in their natural distribution range in the Gulf of Mexico slope, Mexico. Parasitol Res. 2015;114:3337-55.

35. García-Vásquez A, Razo-Mendivil U, Rubio-Godoy M. Triple trouble? Invasive poeciliid fishes carry the introduced tilapia pathogen Gyrodactylus cichlidarum in Mexican highlands. Vet Parasitol. 2017;235:37-40.

36. Song Y, Wang GT, Yao WJ, Gao Q, Nie P. Phylogeny of freshwater parasitic copepods in the Ergasilidae (Copepoda: Poecilostomatoida) based on 185 and 28S rDNA sequences. Parasitol Res. 2008;102:299-306.

37. Boxshall GA. A new species of Ergasilus von Nordmann, 1832 (Copepoda: Cyclopoida) from the gills of a dasyatid ray, Himantura oxyrhyncha (Sauvage, 1878) from West Kalimantan, Indonesia. Zootaxa. 2016;4174:93-103.

38. Van As JG, Van As LL. Argulus izintwala n. sp. (Crustacea: Branchiura) from Lake St Lucia, South Africa. Sys Parasitol. 2001;48:75-9.
Ready to submit your research? Choose BMC and benefit from:

- fast, convenient online submission

- thorough peer review by experienced researchers in your field

- rapid publication on acceptance

- support for research data, including large and complex data types

- gold Open Access which fosters wider collaboration and increased citations

- maximum visibility for your research: over $100 \mathrm{M}$ website views per year

At BMC, research is always in progress.

Learn more biomedcentral.com/submissions 